\title{
Molecular Signature of Early Hepatocellular Carcinoma
}

\author{
Arief Suriawinata $^{a}$ Swan N. Thung ${ }^{b}$ \\ ${ }^{a}$ Department of Pathology, Dartmouth-Hitchcock Medical Center, Lebanon, N.H., and \\ ${ }^{b}$ Lillian and Henry M. Stratton-Hans Popper Department of Pathology, Mount Sinai Medical Center, New York, N.Y., USA
}

\section{Key Words}

Hepatocellular carcinoma, early • Dysplastic nodule •

Molecular signature $\cdot$ Glypican-3

\begin{abstract}
The advances in imaging techniques and establishment of screening and surveillance protocols for high-risk populations for hepatocellular carcinoma (HCC) have led to the detection of small hepatic nodules in patients with chronic liver diseases, but in general the prognosis for HCC remains poor. Early detection of HCC or detection of small/early HCC followed by appropriate treatment is the key to significantly alter the prognosis and significantly decrease tumor-related deaths. Recent advances in gene profiling have led to a better understanding in early hepatocarcinogenesis and have suggested several possible molecular signatures which are able to separate early HCCs from their precursors, the dysplastic nodules. The continued search for new and more accurate molecular signatures must be translated into the clinical setting, where they can advance screening and surveillance of high-risk patients in the detection of early HCC.
\end{abstract}

Copyright $\odot 2010$ S. Karger AG, Basel
(C) 2010 S. Karger AG, Basel

$0030-2414 / 10 / 0787-0036 \$ 26.00 / 0$

Fax +4161306 1234

E-Mail karger@karger.ch

www.karger.com
Accessible online at: www.karger.com/ocl

\section{Introduction}

The incidence of hepatocellular carcinoma (HCC) has been increasing in the last decade in conjunction with the development of cirrhosis in many patients with chronic liver diseases, in particular chronic hepatitis B in Asia and Africa, and chronic hepatitis C in the United States and Europe. Despite the availability of screening programs, the prognosis of HCC globally remains poor, mainly because of late detection in which tumors already show poor prognostic features, such as vascular invasion, multiplicity and large size.

Early detection of HCC, or in other words detection of small or early HCC, followed by appropriate treatment is the key to significantly alter the prognosis and significantly decrease tumor-related deaths in patients with chronic liver diseases. Screening and surveillance programs in Western countries and Japan have indicated that early diagnosis of HCC is feasible in $30-60 \%$ of cases only [1], and that these programs have been fairly successful in the cure of small or early $\mathrm{HCC}(<2 \mathrm{~cm})$. The detection of these nodules of $2 \mathrm{~cm}$ or less poses a diagnostic challenge as they are difficult to characterize by radiological [2] or pathological examination [3].

Tumor markers have been used for clinical diagnosis, screening, surveillance, monitoring response to therapy, monitoring for recurrence after treatment, and estima- 
tion of prognosis. There are several established tumor markers for HCC: $\alpha$-fetoprotein (AFP), lens culinaris agglutinin-reactive AFP (AFP-L3), and des- $\gamma$-carboxy prothrombin (also known as PIVKA-II). Although the serum levels of these tumor markers are generally useful in predicting the prognosis of patients with HCC, their use as screening markers are limited due to their less than ideal sensitivity and specificity $[4,5]$ or the unavailability of a routine laboratory test [6]. Potential novel tumor markers such as glypican-3 (GPC3) [7] and granulin-epithelin precursor [8] are gaining grounds in the diagnosis of HCC with improved sensitivity and specificity, and are used solely or in combination with any of the established markers. Of these novel markers, only GPC3 has been successfully utilized in both serological and immunohistochemical applications for the diagnosis of HCC [9]. GPC3, a membrane-anchored heparan sulfate proteoglycan, has been shown to be expressed in approximately $80 \%$ of HCC but not in benign hepatocellular or metastatic lesions [10]. Identification of other novel markers with higher sensitivity and specificity for early HCC is being carried out by high-throughput genomic and proteomic approaches. In the broader picture, proper genomic and proteomic profiling of tumors will translate to molecular signatures for prevention, diagnosis, classification, targeted therapy and response assessment; which ultimately will lead to personalized treatment for patients.

\section{Molecular Signature and Classification of HCC}

Tumor classification and subclassification are aimed to establish prognosis and to personalize treatment for the best candidates. In addition, they aid researchers in information exchange and in designing clinical trials with comparable criteria. Few molecular data have been incorporated so far in the currently available clinical and pathological classification of HCC. Therefore, the continued search for a new and more accurate molecular signature must be translated into the clinical setting, where it can advance HCC screening and surveillance in the detection of early or small HCC.

Proper definition of nodules as pre-neoplastic lesions or early HCC has critical implications according to the guidelines of HCC management in Europe and the US $[1,11]$. Dysplastic lesions should be followed by regular imaging studies, since one third of them will develop into HCC. Conversely, early or small HCC should be treated with potentially curative procedures, such as resection, transplantation and percutaneous ablation. Therefore, accurate diagnosis of small liver nodules is of paramount importance.

The classification of early or small HCC has proven to be quite problematic, not only that they are difficult to recognize on imaging studies, their subtle differences from the surrounding parenchyma makes them histopathologically difficult to assess. In addition, the nomenclature had been confusing with differences in the diagnostic criteria between Western and Eastern pathologists. Recently, the International Consensus Group for Hepatocellular Neoplasia [12] has put forth diagnostic criteria for low-grade dysplastic nodule, high-grade dysplastic nodule, early HCC, and progressed HCC to better define these small nodules. Although the classification is based mainly on histopathological features and does not specifically incorporate molecular features of early HCC, it has provided universal nomenclature for early HCC and many recent molecular studies have indirectly confirmed the stepwise hepatocarcinogenesis in these early lesions [13-16].

The molecular signature of a specific disease stage should be unique and expressed at elevated levels. Studies suggest that tumors can be classified according to their molecular features or signatures. Furthermore, signatures coming from the tumor and its microenvironment have shown capacity to discriminate subgroups of tumors with different survival outcomes. The incorporation of the knowledge of molecular biology in clinical practice might aid personalized therapy for each patient. Of note, in chronic liver diseases prediction of survival by molecular signatures might be limited due to the fact that patients succumb not only from tumor burden or progression but also from complications of cirrhosis and liver failure.

\section{Hepatocarcinogenesis and Molecular Changes in Early HCC}

Hepatocarcinogenesis is a long-term multistep process involving multiple risk factors and different genetic alterations that ultimately lead to malignant transformation of the hepatocytes [17]. HCC exhibits numerous genetic abnormalities (including chromosomal deletions, rearrangements, aneuploidy, gene amplifications, and mutations), as well as epigenetic alterations (including modulation of DNA methylation). The combination of genetic and epigenetic alterations activates positive mediators of cellular proliferation (including cellular proto- 
Table 1. Molecular studies on early HCC

\begin{tabular}{|c|c|c|c|c|c|c|c|c|c|}
\hline & $\begin{array}{l}\text { Chuma } \\
\text { et al. [20] } \\
2003\end{array}$ & $\begin{array}{l}\text { Nakatsura } \\
\text { et al. [21] } \\
2003\end{array}$ & Paradis et al. [22] 2003 & $\begin{array}{l}\text { Nam } \\
\text { et al. [14] } \\
2005\end{array}$ & $\begin{array}{l}\text { Llovet } \\
\text { et al. [13] } \\
2006\end{array}$ & Mas et al. [23] 2007 & $\begin{array}{l}\text { Wurmbach } \\
\text { et al. [16] } \\
2007\end{array}$ & $\begin{array}{l}\text { Chiang } \\
\text { et al. [24] } \\
2008\end{array}$ & $\begin{array}{l}\text { Moribe } \\
\text { et al. }[25,26] \\
2008 / 2009\end{array}$ \\
\hline $\begin{array}{l}\text { Suggested } \\
\text { genomic } \\
\text { markers }\end{array}$ & HSP70 & GPC3 & $\begin{array}{l}\text { TERT, IGF2, GJB2, TEK, TIAM1, } \\
\text { CXCL12, TOP2A, A2M, PLG, } \\
\text { ARF, PDGF, MKI67, THBS1 }\end{array}$ & $\begin{array}{l}120 \text { genes } \\
\text { for early } \\
\text { stage HCC }\end{array}$ & $\begin{array}{l}\text { GPC3, } \\
\text { LYVE, } \\
\text { Survivin }\end{array}$ & $\begin{array}{l}\text { VEGF, EGFL3, EGFR, } \\
\text { VEGFB, PDGF, ANG, } \\
\text { AGPTL2, TIMP2, ICAM2 }\end{array}$ & $\begin{array}{l}\text { GPC3, } \\
\text { XLKD1, } \\
\text { BIRC1 }\end{array}$ & VEGFA & $\begin{array}{l}\text { BASP1, } \\
\text { SRD5A2 }\end{array}$ \\
\hline
\end{tabular}

oncogenes and their mitogenic signaling pathways) and inactivates negative mediators of cellular proliferation (including tumor suppressor genes), resulting in cells with autonomous growth potential.

In the cirrhotic liver, it has been shown that genes with functions in the immune response and cell adhesion were upregulated, and genes involved in metabolism showed varying alterations. These results reflect the transition from normal to cirrhosis, where the liver function becomes impaired and extracellular matrix deposition increases $[18,19]$. In HCC, genes whose products had functions in cell cycle, protein biosynthesis and RNA processing, cell division, DNA replication, protein modification, ubiquitin cycle, or chromatin modulation were upregulated. Conversely, genes linked to the immune response, cytokine-cytokine receptor interactions, Ca signaling, the Jak/STAT pathway, and blood coagulation were downregulated. The progression of HCC to advanced stages was characterized by additional upregulation of genes involved in cell cycle regulation [16].

The study of tissue markers should be able to distinguish early HCC from other entities and, eventually, should be further tested as serum markers for surveillance and treatment purposes. A recent gene expression profiling study by Wurmbach et al. [16] reported the molecular signatures in 75 tissue samples from patients with hepatitis $\mathrm{C}$ virus $(\mathrm{HCV})$ that accurately discriminated the progression from normal to cirrhosis (8 genes), cirrhosis to dysplasia (24 genes), dysplasia to early HCC (94 genes), and early to advanced HCC (9 genes). This study had successfully described dysregulated genes throughout all stages of HCV-induced HCC and in the early stages of hepatocarcinogenesis, which may play an important role in the progression of the disease. A similar study by Nam et al. [14] performed earlier had reached a similar conclusion.

In the last few years many other studies have found molecular changes in HCC, many of which are potential markers or signatures of early HCC (table 1). From ta- ble 1, genes such as GPC3 appeared repetitively in many studies which validated its role in hepatocarcinogenesis and strong candidacy as molecular signature of early HCC.

\section{Future Directions}

The current knowledge of molecular signatures of early $\mathrm{HCC}$ is preliminary and further studies are required to elucidate hepatocarcinogenesis in concordance with histopathological classification of early HCC. Many of the investigations have presented promising progress in the use of gene expression profiling in elucidating the molecular pathogenesis of HCC. Gene expression profiling studies will allow identification of molecular signatures of HCC that are useful as screening and surveillance tools and for predicting the risk of HCC development in cirrhotic tissue and this will eventually lead to personalized treatment for $\mathrm{HCC}$ in the broader picture.

\section{Disclosure Statement}

The authors declare that they have no financial conflict of interest.

References

$\checkmark 1$ Bruix J, Sherman M: Management of hepatocellular carcinoma. Hepatology 2005;42: 1208-1236.

-2 Bolondi L, Gaiani S, Celli N, Golfieri R, Grigioni WF, Leoni S, Venturi AM, Piscaglia F: Characterization of small nodules in cirrhosis by assessment of vascularity: the problem of hypovascular hepatocellular carcinoma. Hepatology 2005;42:27-34.

-3 Kojiro M: Focus on dysplastic nodules and early hepatocellular carcinoma: an Eastern point of view. Liver Transpl 2004;10:S3-S8.

4 Sherman M: Alphafetoprotein: an obituary. J Hepatol 2001;34:603-605. 
5 Nomura F, Ishijima M, Kuwa K, Tanaka N, Nakai T, Ohnishi K: Serum des-gamma-carboxy prothrombin levels determined by a new generation of sensitive immunoassays in patients with small-sized hepatocellular carcinoma. Am J Gastroenterol 1999;94: 650-654.

-6 Poon TC, Mok TS, Chan AT, Chan CM, Leong V, Tsui SH, Leung TW, Wong HT, Ho SK, Johnson PJ: Quantification and utility of monosialylated alpha-fetoprotein in the diagnosis of hepatocellular carcinoma with nondiagnostic serum total alpha-fetoprotein. Clin Chem 2002;48:1021-1027.

-7 Capurro M, Wanless IR, Sherman M, Deboer G, Shi W, Miyoshi E, Filmus J: Glypican-3: a novel serum and histochemical marker for hepatocellular carcinoma. Gastroenterology 2003;125:89-97.

$>8$ Cheung ST, Wong SY, Leung KL, Chen X, So S, Ng IO, Fan ST: Granulin-epithelin precursor overexpression promotes growth and invasion of hepatocellular carcinoma. Clin Cancer Res 2004;10:7629-7636.

-9 Shirakawa H, Kuronuma T, Nishimura Y, Hasebe T, Nakano M, Gotohda N, Takahashi S, Nakagohri T, Konishi M, Kobayashi N, Kinoshita T, Nakatsura T: Glypican-3 is a useful diagnostic marker for a component of hepatocellular carcinoma in human liver cancer. Int J Oncol 2009;34:649-656.

10 Nassar A, Cohen C, Siddiqui MT: Utility of glypican-3 and survivin in differentiating hepatocellular carcinoma from benign and preneoplastic hepatic lesions and metastatic carcinomas in liver fine-needle aspiration biopsies. Diagn Cytopathol 2009;37:629-635.

11 Bruix J, Sherman M, Llovet JM, Beaugrand M, Lencioni R, Burroughs AK, Christensen E, Pagliaro L, Colombo M, Rodes J; EASL Panel of Experts on HCC: Clinical management of hepatocellular carcinoma. Conclusions of the Barcelona-2000 EASL conference. European Association for the Study of the Liver. J Hepatol 2001;35:421-430.
12 International Consensus Group for Hepatocellular neoplasia: Pathologic diagnosis of early hepatocellular carcinoma: a report of the international consensus group for hepatocellular neoplasia. Hepatology 2009;49: 658-664.

13 Llovet JM, Chen Y, Wurmbach E, Roayaie S, Fiel MI, Schwartz M, Thung SN, Khitrov G, Zhang W, Villanueva A, Battiston C, Mazzaferro V, Bruix J, Waxman S, Friedman SL: A molecular signature to discriminate dysplastic nodules from early hepatocellular carcinoma in HCV cirrhosis. Gastroenterol ogy 2006;131:1758-1767.

14 Nam SW, Park JY, Ramasamy A, Shevade S, Islam A, Long PM, Park CK, Park SE, Kim SY, Lee SH, Park WS, Yoo NJ, Liu ET, Miller LD, Lee JY: Molecular changes from dysplastic nodule to hepatocellular carcinoma through gene expression profiling. Hepatology 2005;42:809-818.

15 Paradis V, Dargere D, Bonvoust F, RubbiaBrandt L, Ba N, Bioulac-Sage P, Bedossa P: Clonal analysis of micronodules in virus $\mathrm{C}$ induced liver cirrhosis using laser capture microdissection (LCM) and HUMARA assay. Lab Invest 2000;80:1553-1559.

16 Wurmbach E, Chen YB, Khitrov G, Zhang W, Roayaie S, Schwartz M, Fiel I, Thung S, Mazzaferro V, Bruix J, Bottinger E, Friedman S, Waxman S, Llovet JM: Genome-wide molecular profiles of HCV-induced dysplasia and hepatocellular carcinoma. Hepatology 2007;45:938-947.

17 Suriawinata A, Xu R: An update on the molecular genetics of hepatocellular carcinoma. Semin Liver Dis 2004;24:77-88.

18 Albanis E, Friedman SL: Antifibrotic agents for liver disease. Am J Transplant 2006;6:1219.

19 Hoshida Y, Villanueva A, Kobayashi M, Peix J, Chiang D, Camargo A, et al: Gene expression in fixed tissues and outcome in hepatocellular carcinoma. N Engl J Med 2008;359: 1995-2004.
20 Chuma M, Sakamoto M, Yamazaki K, Ohta T, Ohki M, Asaka M, Hirohashi S: Expression profiling in multistage hepatocarcinogenesis: identification of HSP70 as a molecular marker of early hepatocellular carcinoma. Hepatology 2003;37:198-207.

21 Nakatsura T, Yoshitake Y, Senju S, Monji M, Komori H, Motomura Y, et al: Glypican-3, overexpressed specifically in human hepatocellular carcinoma, is a novel tumor marker. Biochem Biophys Res Commun 2003;306: 16-25.

22 Paradis V, Bieche I, Dargere D, Laurendeau I, Laurent C, Bioulac-Sage P, Degott C, Belghiti J, Vidaud M, Bedossa P: Molecular profiling of hepatocellular carcinomas (HCC) using a large-scale real-time RT-PCR approach: determination of a molecular diagnostic index. Am J Pathol 2003;163:733-741.

-23 Mas VR, Maluf DG, Archer KJ, Yanek KC, Fisher RA: Angiogenesis soluble factors as hepatocellular carcinoma noninvasive markers for monitoring hepatitis $\mathrm{C}$ virus cirrhotic patients awaiting liver transplantation. Transplantation 2007;84:1262-1271.

24 Chiang DY, Villanueva A, Hoshida Y, Peix J, Newell P, Minguez B, et al: Focal gains of VEGFA and molecular classification of hepatocellular carcinoma. Cancer Res 2008;68: 6779-6788.

25 Moribe T, Iizuka N, Miura T, Stark M, Tamatsukuri S, Ishitsuka $\mathrm{H}$, et al: Identification of novel aberrant methylation of BASP1 and SRD5A2 for early diagnosis of hepatocellular carcinoma by genome-wide search. Int J Oncol 2008;33:949-958.

26 Moribe T, Iizuka N, Miura T, Kimura N, Tamatsukuri $\mathrm{S}$, Ishitsuka $\mathrm{H}$, Hamamoto $\mathrm{Y}$, Sakamoto K, Tamesa T, Oka M: Methylation of multiple genes as molecular markers for diagnosis of small, well-differentiated hepatocellular carcinoma. Int J Cancer 2009;125: 388-397. 